\title{
Impact of surface contamination on elemental composition of Sanguinea (Pall.) leaves
}

\author{
Valentina A. Sagaradze ${ }^{1 *}$,Elena Y. Babaeva ${ }^{1}$, Yulia V. Zagurskaya ${ }^{2}$ and Tatyana \\ I. Siromlya ${ }^{3}$ \\ ${ }^{1}$ All-Russian Sci. Research Institute of Medicinal and Aromatic Plants, 117216, Moscow, Russia \\ ${ }^{2}$ Federal Research Center on Coal and Coal Chemistry SB RAS (Institute of Human Ecology), \\ 650065 Kemerovo, Russia \\ ${ }^{3}$ Institute of Soil Science and Agrochemistry SB RAS, 630090 Novosibirsk, Russia
}

\begin{abstract}
The leaves of $C$. sanguinea Pall. have the potential to accumulate dust on the surface. As the fine dust particles contain various chemical elements (ChEs), we studied the ChE composition in the leaves with different degrees of dust contamination to assess the impact on assay results. The samples of $C$. sanguinea leaves collected in the Kemerovo region (Russia) were divided into two groups based on the visual condition of plant material: clean leaves and dust contaminated leaves. The total ash assay revealed higher ash content, exceeding pharmacopoeial standards in the dust contaminated group. Dust contaminated leaf samples demonstrated significantly higher concentrations of many $\mathrm{ChE}$ : $\mathrm{Si}, \mathrm{Fe}, \mathrm{Al}, \mathrm{Na}, \mathrm{Ti}, \mathrm{Ni}, \mathrm{Zr}, \mathrm{Cr}, \mathrm{V}, \mathrm{Pb}, \mathrm{La}$, $\mathrm{Ga}, \mathrm{Y}, \mathrm{Sc}$ and $\mathrm{Yb}$ comparing to non-contaminated plant material. The values of potentially hazardous ChEs were significantly lower than the maximum levels specified for medicinal raw materials in all studied samples.
\end{abstract}

\section{Introduction}

Crataegus sanguinea Pall. is the most prevalent medicinal species of hawthorn in Russian flora. Hawthorn flowers and fruits (Crataegi flores, Crataegi fructus) are included in the register of medicinal raw material (MRM) in the State Pharmacopeia of the Russian Federation (SP RF) [1]. However, leaves or leaves with flowers of hawthorn (Crataegi folia, Crataegi folia cum flores) are more common in the world medical practice [2-4, etc.]. Therefore, Russian researchers have initiated studies of hawthorn leaves, collected from domestic species, for potential addition to the list of MRM [5-7].

The usage of hawthorn leaves or flowers with leaves as an alternative to pharmacopoeial MRM seems promising as harvesting of hawthorn leaves is more effective in comparison to the harvesting of flowers. However, the studies on hawthorn leaves, especially on chemical element $(\mathrm{ChE})$ composition remain limited due to the conventional use of other hawthorn MRM sources such as flowers and fruits and the

\footnotetext{
* Corresponding author: sagaradze@ vilarnii.ru
} 
predominant utilization of several species, widely distributed in the European part of Russia.

Furthermore, extensive accumulation of solid environment pollutants on pubescent leaf surface can limit the harvesting even in areas remoted from settlements. Since contamination of plant material with highly dispersed soil particles can take a great share in a significant increase of several $\mathrm{ChE}$, including potentially hazardous to human ChE presented mostly in poorly soluble forms [8-10].

The total ash assay of plant material especially allows estimating the proportion of mineral impurities that reflects dustiness. The upper limit of total ash content for hawthorn flowers is $12 \%$ according to the SP PF [1], which likewise corresponds to a similar standard for hawthorn leaves in the SP RB [4]. The study aims to compare the ChE composition of $C$. sanguinea leaves with different degrees of dust contamination.

\section{Materials and Methods}

\subsection{Object of study}

The leaves of Crataegus sanguinea Pall. were collected in August, 2016 on the territory of the "Kedrovskiy" coal pit (Kemerovo city). The leaves were gathered from the middle part of the shoot. The samples were divided into groups: 1) clean leaves 2) leaves with obvious dust contamination. Each sample from different plants was analyzed severally. Plant material was air-dried and stored at room temperature.

Taxonomic identification was established by taxonomist R. A. Ufimov, PhD. Voucher specimens (LE 01020943, LE 01020944, LE 01020945, LE 01020946, LE 01020947) were deposited in the Herbarium of Vascular Plants of the Komarov Botanical Institute of the RAS, Saint-Petersburg. The Plant names are provided according to World Flora Online database [11].

\subsection{Methods of study}

Total ash assay was conducted according to requirements of the State Pharmacopoeia of the Russian Federation, Edition 14 [1]. The ChE composition was studied by atomic emission spectrometry after dry ashing. Тhe As и $\mathrm{Hg}$ were assayed by atomic absorption spectrometry. Analyses were conducted in triplicate. The samples of birch leaf (LB-1) GSO 8923-2007 and Elodea canadensis Michx. (EC-1) were used as standards. The results of the ChE assay in the references were within their certified values. The data are given in terms of absolutely dry matter. The observation of epidermal trichomes was conducted with a binocular microscope MBS 10 [1].

\subsection{Statistics}

Statistical evaluation of experimental results was carried out with STATISTICA 6.1 software. The normality of all data was analyzed by Shapiro-Wilk's test. The homogeneity of dispersions was analyzed using Cochran's Q-test. All normally distributed data were analyzed using Student t-test, in other cases, Mann-Whitney U-test was applied. $p \leq 0.05$ were considered to be significant. Data on figures are presented as medians and $25^{\text {th }}-, 75^{\text {th }}$-percentiles, and minimum and maximum values.

\section{Results and discussion}


The structural peculiarities of leaf surface are important for the dust holding capacity of plants [12-14]. In particular, simple unicellular trichomes and leaf teeth glands were observed on the epidermis of $C$. sanguinea specimens.

Total ash assay of clean leaves (C) revealed the values of $10.1-11.9 \%$, which meet the requirements of the SP PF [1], while the ash content of dust contaminated samples (D) was $12.3-15.6 \%$.

The amount of potentially hazardous ChE, did not exceed the Pharmacopoeial limits for MRM, (content in samples, mg / kg / maximum level, $\mathrm{mg} / \mathrm{kg}$ ): As <0.03 / 0.5 [1]; Cd 0.06-0.17 / 1.0 [1, 2]; Pb 0.7 - 1.9 / 6.0 [1] and 5.0 [2]; $\mathrm{Hg}<0,01 / 0,1$ [1, 2].

However, significant differences in several $\mathrm{ChE}$ concentration were detected between compared groups of samples. (Fig. 1). Thus, ChE composition analysis of dust contaminated leaves revealed higher concentrations of $\mathrm{Si}, \mathrm{Fe}, \mathrm{Al}, \mathrm{Na}, \mathrm{Ti}, \mathrm{Ni}, \mathrm{Zr}, \mathrm{Cr}, \mathrm{V}$, $\mathrm{Pb}, \mathrm{La}, \mathrm{Ga}, \mathrm{Y}, \mathrm{Sc}$ and $\mathrm{Yb}$.

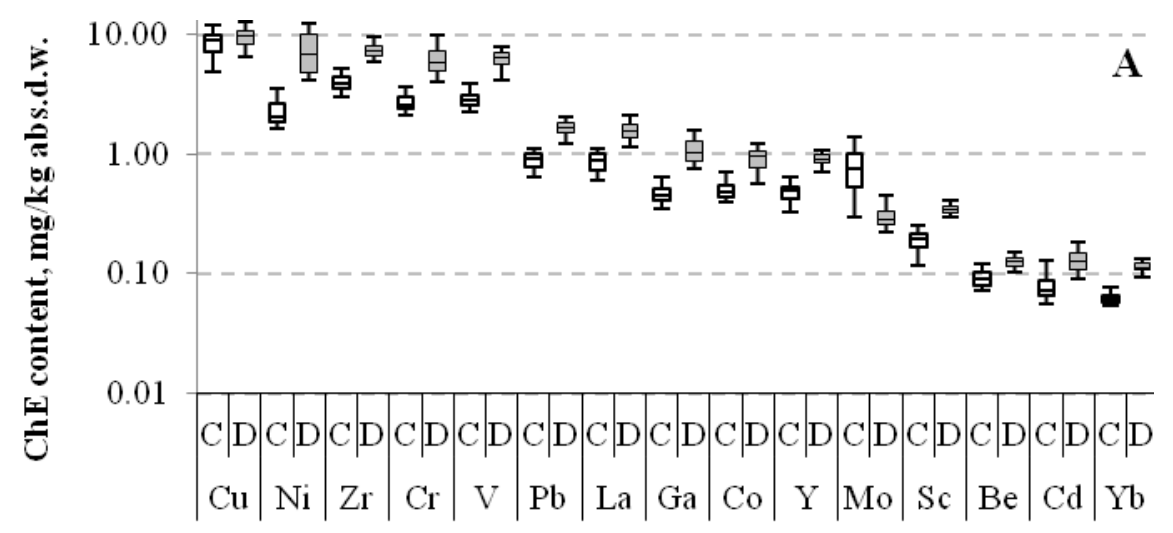

Element / Sample

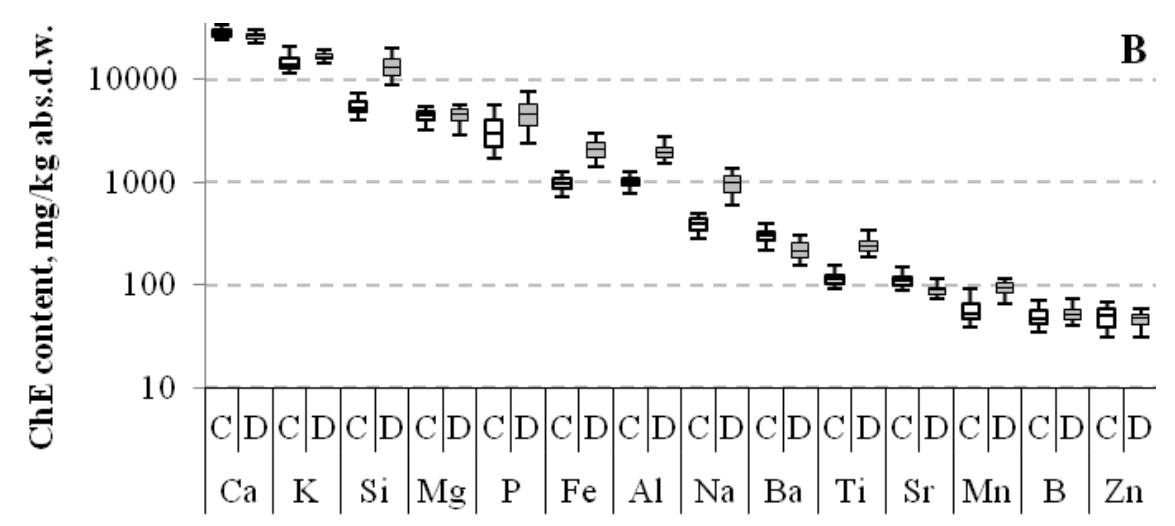

Element / Sample

Fig. 1. Content of chemical elements in the conditionally clean (C) and dusty (D) leaves Crataegus sanguinea on the territory of the "Kedrovskiy" coal pit (Kemerovo city): A - ChE content $0,001-15 \mathrm{mg} / \mathrm{kg}$; B $-\mathrm{ChE}$ content $10-50000 \mathrm{mg} / \mathrm{kg}$.

The established list of chemical elements generally coincides with our data previosly obtained in the study of Leonurus quinquelobatus Gilib., Artemisia sieversiana Ehrh. ex Willd., Urtica cannabina L., Populus tremula L. [14]. 
C. Reimann et al. [13] also have reported that high values of $\mathrm{Al}$ and Fe can be taken as the first indicators of the possible influence of minerogenic dust on the observed ChE concentration in plant material. Considering that detecting a number of elements in some species (for example, $\mathrm{Cr}, \mathrm{Li}, \mathrm{Sc}$ and $\mathrm{Th}$ ) is complicated, the best indicators of plant material dustiness are $\mathrm{Al}, \mathrm{Fe}, \mathrm{Si}, \mathrm{V}, \mathrm{Y}$ and $\mathrm{Zr}[15,16]$.

The studies on ChE in leaves of $C$. sanguinea leaves appeared only in two publications introduced by Russian authors. With that, those investigations were devoted to a limited number of heavy metals. The ranges of $\mathrm{Cd}, \mathrm{Co}, \mathrm{Cu}, \mathrm{Mn}$ and $\mathrm{Zn}$ content revealed during our studies were comparable with the results of other researchers $[17,18]$. The observed content of $\mathrm{Ni}$ in non-contaminated leaves was close to the values presented in the literature [17]. However, the total $\mathrm{Pb}$ content was slightly higher than that found in the leaves of hawthorn plants in the Orenburg city [18].

\section{Conclusion}

The dust contamination of the leaf surface impacts Che composition ( $\mathrm{Si}, \mathrm{Fe}, \mathrm{Al}, \mathrm{Na}, \mathrm{Ti}$, $\mathrm{Ni}, \mathrm{Zr}, \mathrm{Cr}, \mathrm{V}, \mathrm{Pb}, \mathrm{La}, \mathrm{Ga}, \mathrm{Y}, \mathrm{Sc}$ and $\mathrm{Yb}$ ) assay in the plant material, which is especially noticeable for pubescent leaves. At the same time, a significant part of the elements is contained not in plant tissues, but finely dispersed soil particles enriched with $\mathrm{ChE}$ and accumulated on their surface. The excess of the standardized limits of $\mathrm{ChE}$ ( $\mathrm{As}, \mathrm{Hg}, \mathrm{Cd}$, $\mathrm{Pb}$ ) did not occur.

We thank R. A. Ufimov, PhD, Austrian Research and Training Centre for Forests, Natural Hazards and Landscapes, Vienna, for taxonomic identification of the raw material of Crataegus.

The research was supported All-Russian Sci. Research Institute of Medicinal and Aromatic Plants assignment FNSZ -2019-0008 (AAAA-A19-119112590084-5), Institute of Soil Science and Agrochemistry SB RAS assignment (121031700309-1) and Federal Research Center on Coal and Coal Chemistry SB RAS (Institute of Human Ecology) assignment № 0286-2021-0010 (NIOKTR № AAAA-A21-121011590010-5).

\section{References}

1. The State Pharmacopoeia of the RF. XIV ed., V. 4 (Moscow, Min. Zdrav. RF, 2018)

2. European Pharmacopoeia. $10^{\text {th }}$ ed., V. 1 (Council of Europe, Strasbourg, 2019)

3. United States Pharmacopeia 33. National Formulary 28, Sec. Suppl. (United States Pharmacopeial Convention, Rockville, Md, 2012)

4. The State Pharmacopoeia of the Republic of Belarus, 2 ("Pobeda", Molodechno, 2007)

5. V. A. Kurkin, T. V. Morozova, O. E. Pravdivtseva, Chemistry of plant raw materials, 3 (2017)

6. S. V. Trofimova, S. R. Khasanova, N. V. Kudashkina, N. Zh. Baschenko, T. A. Sapozhnikova, R. Yu. Hisamutdinova, Bashkortostan Med. J., 6(2) (2011)

7. V. A. Sagaradze, E. Yu. Babaeva, R. A. Ufimov, Yu. V. Zagurskaya, N. A. Trusov, I. N. Korotkikh, V. I. Markin, E. V. Peschanskaya, G. F. Mozhaeva, E.I.

Kalenikova, Chemistry of plant raw materials, 4 (2018)

8. A. van der Ent, A. J. M. Baker, R. D. Reeves, A. J. Pollard, H.Schat, Plant Soil, 362 (2013) 
9. Y. V. Zagurskaya, T. I. Siromlya, Uch. Zap. Kaz. Univ. Ser. Estestv. Nauki, 3 (2018)

10. L. P. Rybashlykova, Probl. Bio., Med. \& Pharm. Chem., 5 (2017)

11. WFO (2021): World Flora Online. URL http://www.worldfloraonline.org

12. A. Sæb $\varnothing$, R. Popek, B. Nawrot B., H. M. Hanslin, H. Gawronska, S. W. Gawronski, Sci. Total Envir., 427-428 (2012)

13. R. J. Leonard, C. McArthur, D. F. Hochuli, Urban For. \& Urban Gree., 20 (2016)

14. T. I. Siromlya, Y. V. Zagurskaya, Journal of General Biology, 82(4) (2021)

15. C. Reimann, F. Koller, B. Frengstad, G. Kashulina, H. Niskavaara, P. Englmaier, Sci. Total Environm., 278 (2001)

16. R. Bargagli, Trace Elements in Terrestrial Plants: An Ecophysiological Approach to Biomonitoring and Biorecovery (Berlin, Springer-Verlag, 1998)

17. S. V. Mukhametova, Selection and breeding methods of hawthorn (Crataegus L.). (Yoshkar-Ola, 2017)

18. D. G. Fedorova, G. V. Karpova, B. S. Ukenov, IOP Conf. Ser.: Earth \& Environm. Sci., 670 (2021) 